Envisioning Future Media Environments (pp. 9-15). New York, NY: ACM. Retrieved from https: //www.cs.auckland.ac.nz/courses/compsci747s2c/lectures/paul/definition-deterding.pdf

Downs-Le Guin, T., Baker, R., Mechling, J., \& Ruylea, E. (2012). Myths and realities of respondent engagement in online surveys. International Journal of Market Research, 54(5), 1-21. doi:10.2501/IJMR-54-5-000-000

Ferrell, J. Z., Carpenter, J. E., Vaughn, E. D., Dudley, N. M., \& Goodman, S. A. (2015). Gamification of human resource processes. In D. Davis \& H. Gangadharbatla (Eds.), Emerging research and trends in gamification (pp. 108-139). Hershey, PA: IGI Global.

Garris, R., Ahlers, R., \& Driskell, J. E. (2002). Games, motivation, and learning: A research and practice model. Simulation \& Gaming, 33(4), 441-467. doi:10.1177/1046878102238607

Hamari, J., Koivisto, J., \& Sarsa, H. (2014). Does gamification work? A literature review of empirical studies on gamification. Proceedings of the 47th Hawaii International Conference on System Sciences, Waikoloa, HI.

Landers, R. N. (2014). Developing a theory of gamified learning: Linking serious games and gamification of learning. Simulation \& Gaming, 45(6), 752-768. doi:10.1177/1046878114563660

Landers, R. N., Bauer, K. N., \& Callan, R. C. (in press). Gamification of task performance with leaderboards: A goal setting experiment. Computers in Human Behavior. doi:10.1016/j.chb.2015.08.008

Landers, R. N., Bauer, K. N., Callan, R. C., \& Armstrong, M. B. (2015). Psychological theory and the gamification of learning. In T. Reiners \& L. Wood (Eds.), Gamification in education and business (pp. 165-186). Cham, Switzerland: Springer.

Lievens, F., Peeters, H., \& Schollaert, E. (2008). Situational judgment tests: A review of recent research. Personnel Review, 37, 426-441.

Locke, E. A., \& Latham, G. P. (2013). Goal setting theory, 1990. In E. A. Locke \& G. P. Latham (Eds.), New developments in goal setting and task performance (pp. 3-15). New York, NY: Routledge/Taylor \& Francis.

Popp, E. (2014, May). Challenges and innovations of using game-like assessments in selection. Symposium conducted at the 29th Annual Conference of the Society for Industrial and Organizational Psychology, Honolulu, HI.

Walz, S. P., \& Deterding, S. (2015). An introduction to the gameful world. In S. P. Walz \& S. Deterding (Eds.), The gameful world: Approaches, issues, applications (pp. 1-13). Cambridge, MA: MIT Press.

Yan, T., Conrad, F. G., Tourangeau, R., \& Couper, M. P. (2011). Should I stay or should I go: The effects of progress feedback, promised task duration, and length of questionnaire on completing web surveys. International Journal of Public Opinion Research, 23(2), 131-147. doi:10.1093/ijpor/edq046

\title{
Moving Beyond Identification: Using Gamification To Attract and Retain Talent
}

\author{
Graham H. Lowman \\ University of Alabama
}

Graham H. Lowman, Department of Management, University of Alabama.

Correspondence concerning this article should be addressed to Graham H. Lowman, Department of Management, University of Alabama, 361 Stadium Drive, Tuscaloosa, AL 35487. E-mail: ghlowman@crimson.ua.edu 
As noted in the focal article (Chamorro-Premuzic, Winsborough, Sherman, \& Hogan, 2016), recent advances in technology have provided new tools for talent identification; however, identification alone is not enough to win the war for talent (Chambers, Foulon, Handfield-Jones, Hankin, \& Michael, 1998). Big data, social media, and mobile apps provide access to previously untapped information about individuals; unfortunately, that information has limited value if it cannot be used to attract and retain the top talent it identifies. Therefore, new tools for talent identification must also be vetted for how well they provide human resource (HR) practitioners a means for attracting top talent and retaining that talent. Although far from a silver bullet, gamification opens the door for collecting information on an individual's talent potential while also fostering organizational attraction and employee retention.

\section{What Is Gamification?}

Gamification is "the use of game design elements in non-game contexts" (Deterding, Dixon, Khaled, \& Nacke, 2011, p. 9). This definition identifies the four primary components of gamification. First, gamification deals with gaming as opposed to playing. The distinction is a critical one, as playing refers to improvisational and expressive behavior, whereas gaming refers to playing within a set of rules with the purpose of obtaining a goal or specific outcome. Additionally, actors in games are faced with difficulties often in a competitive environment. The second component of the gamification is the design. Unlike traditional games, gamification refers to the use of only a certain set of game elements. These elements compose the third component of gamification, which refers to the characteristics or features that are found in most games, that are associated with games, or that contribute to gameplay. Game characteristics and features entail design patterns, game mechanics, conceptual models and principles, and design methods. The final component of gamification is use in a nongame context. This final component of gamification is critical as it opens the door for leveraging the benefits of gaming in nontraditional gaming contexts.

The use of gamification has exploded in recent years, especially in the development of mobile apps and computer-based simulation games. The business world has also warmed up to gamification as more gamer friendly millennials enter the workforce and the benefits of gaming are better understood (Seaborn \& Fels, 2015). For example, gaming as a form of active learning leads to a $75 \%$ retention rate as opposed to passive learning (e.g., watching a training video), which has a $10 \%$ retention rate (Beck \& Wade, 2013). Additionally, gaming encourages trial and error learning, calculated risk-taking, and cooperation in goal attainment, all of which are necessary within the workplace (Beck \& Wade, 2013). 
The current application of gamification in the workplace has focused primarily on enhancing employee engagement (Seaborn \& Fels, 2015). For instance, AirBaltic Corporation recently implemented a gamified electronic platform to improve employee engagement (Ergle, 2015). However, as the focal article suggests, the use of gamification within the workplace also provides a viable means for collecting information about potential employees and identifying talent. In addition to identification, gamification can also be used to attract and retain talent. Therefore, gamification is an effective tool for winning the war for talent by providing HR practitioners an innovative tool to identify, attract, and retain talent.

\section{Examples of Gamification To Identify and Attract Talent}

America's Army is a prime example of utilizing gamification to identify and attract talent. The game was developed and released by the U.S. Army in 2002 as a recruitment tool and has been hugely successful, with numerous revisions and updates over the past 14 years. Providing civilians the opportunity to experience combat as a soldier not only provides a realistic job preview but also allows the U.S. Army to collect data on participants. This information is invaluable to identifying high talent individuals. For example, the game provides training and skill development that mirror the techniques implemented in actual soldier training. Therefore, individuals who advance quickly through the ranks in virtual training and skill development are likely to excel in real-life training and skill development as well. The Army can then target these high profile candidates for recruitment.

The U.S. Army also uses America's Army to attract talent. The feel of the game, the options and controls made available to players, and even the design of the game portal are created to attract potential soldiers. In essence, the game is an interactive advertisement for the U.S. Army. Additionally, the use of a high-fidelity game with attractive rewards encourages immersion in the virtual environment and increases an individual's desire to play the game in the future (Ryan, Rigby, \& Przybylski, 2006). As individuals return to play the game, they are repeatedly exposed to U.S. Army promotion and advertisement. Due to this repetitive exposure to complex stimuli, individuals who play America's Army regularly are likely to have a favorable view toward the U.S. Army (Bornstein, 1989). This, in turn, should improve the U.S. Army's ability to attract high talent individuals who play the game on a regular basis.

The matching concept employed by dating apps is a second example of how gamification can be used for talent identification and attraction. The focal article uses the Tinder mobile app as an example of how HR practitioners can assess person-environment fit (Edwards, 2008) by viewing potential candidates' social profile information. Although this means of identifying 
talent is not unique, it does provide a significant upgrade to static job boards (e.g., Monster, Indeed). Specifically, it allows for active recruitment of high talent candidates that fit an organization's culture and values as opposed to passively waiting for resumes and referrals.

However, the matching concept implemented by dating games such as Tinder also provides a unique avenue for enhancing the attractiveness of an organization to potential job candidates. For example, an organization could develop an app that would allow potential candidates to "like" specific jobs within the organization they find attractive and allow HR practitioners to "like" potential high talent candidates based on their social profiles. The process of liking a specific job, anticipating a like back from the organization, and receiving a match increases dopamine activity in the brain (Schultz, 1998). Similar to other games (Koepp et al., 1998), this could result in job candidates developing a strong attachment to the game and the organization, as dopamine has a direct influence on an individual's desire to obtain an incentive (e.g., a job match) and regulates the reward and pleasure centers in the brain (Berridge \& Robinson, 1998). Additionally, the immediate notification of a match via a candidate's smartphone could also improve the attractiveness of the organization. The instant feedback signals to potential candidates that the organization is actively interested and conveys that the organization perceives a person-organization fit, both of which increase organizational attractiveness (Dineen, Ash, \& Noe, 2002).

\section{Examples of Gamification To Identify and Retain Talent}

Along with providing HR practitioners an innovate tool for identifying and attracting external talent, gamification can also help identify and retain talent within the organization. This is most evident through the use of training games designed for career development. For example, Electronic Arts (EA) developed an internal training program called EA University. The goal of the program is to train employees while also utilizing the benefits of gamification that EA has learned from developing video games. As a result, EA provides employees the opportunity to participate in game-based learning for developing valuable skills within an engaging and dynamic environment. Similar to America's Army, EA University allows the organization to track employee behavior and development throughout the training game process. Top talent can be identified by monitoring the speed at which employees complete challenging games and successfully collaborate with other employees participating in the games. The autonomy given to employees to solve and master challenging problems as part of the training appeals to intrinsic motivators and fosters engagement (Ryan \& Deci, 2000). Given that employee engagement leads to a decrease in employee turnover 
(Harter, Schmidt, \& Hayes, 2002), creating an engaging learning environment for employees will also lead to improved employee retention.

An additional method for identifying and retaining talent is through the use of virtual employee profiles and achievement systems. As employees progress through training programs, participate in special work projects, maintain a high level of performance, or participate in volunteer activities, they earn achievements (e.g., badges) to attach to their virtual profile. The most basic application is to use badges to identify talented employees. However, an organization can take this one step further by allowing employees to "cash-out" badges for real-world rewards and benefits. Additionally, organizations can post leaderboards to recognize employees with the most badges or difficult to obtain badges as a method of encouraging engagement and competition among employees. These kinds of achievement systems, paired with rewards that employees value, can be used by HR practitioners to keep employees engaged, foster community, and ultimately improve retention by creating an engaging work environment.

\section{The Future of Gamification}

Gamification is quickly becoming a multibillion dollar industry, and in many ways the industry has outpaced academic research. As organizations begin to leverage gamification to improve organizational and employee outcomes, researchers should continue to engage and attempt to understand the impacts of gamification on the workplace. For HR practitioners, the examples introduced here provide a small glimpse into the possibilities of gamification for identifying, attracting, and retaining talent. With industry and research advancing, gamification should become a valuable weapon for winning the war for talent.

\section{References}

Beck, J. C., \& Wade, M. (2013). The kids are alright: How the gamer generation is changing the workplace. Boston, MA: Harvard Business Press.

Berridge, K. C., \& Robinson, T. E. (1998). What is the role of dopamine in reward: Hedonic impact, reward learning, or incentive salience? Brain Research Reviews, 28(3), 309-369.

Bornstein, R. F. (1989). Exposure and affect: Overview and meta-analysis of research, 1968-1987. Psychological Bulletin, 106(2), 265-289.

Chambers, E., Foulon, M., Handfield-Jones, H., Hankin, S., \& Michael, E., III. (1998). The war for talent. The McKinsey Quarterly, 3, 44-57.

Chamorro-Premuzic, T., Winsborough, D., Sherman, R. A., \& Hogan, R. (2016). New talent signals: Shiny new objects or a brave new world? Industrial and Organizational Psychology: Perspectives on Science and Practice, 9(3), 621-640.

Deterding, S., Dixon, D., Khaled, R., \& Nacke, L. (2011, September). From game design elements to gamefulness: Defining gamification. In A. Lugmayr (Chair). Proceedings of the 15th International Academic MindTrek conference: Envisioning future media environments (pp. 9-15). Tempere, Finland: ACM. Retrieved from http://dl.acm.org/citation.cfm?id=2181037 
Dineen, B. R., Ash, S. R., \& Noe, R. A. (2002). A web of applicant attraction: Person-organization fit in the context of web-based recruitment. Journal of Applied Psychology, 87(4), 723-724.

Edwards, J. R. (2008). 4 person-environment fit in organizations: An assessment of theoretical progress. The Academy of Management Annals, 2 (1), 167-230.

Ergle, D. (2015). Fostering employee engagement through gamification: AirBaltic Forecaster Tool. Management, 10(3), 219-234.

Harter, J. K., Schmidt, F. L., \& Hayes, T. L. (2002). Business-unit-level relationship between employee satisfaction, employee engagement, and business outcomes: A meta-analysis. Journal of Applied Psychology, 87(2), 268-279.

Koepp, M. J., Gunn, R. N., Lawrence, A. D., Cunningham, V. J., Dagher, A., Jones, T., .. Grasby, P. M. (1998). Evidence for striatal dopamine release during a video game. Nature, 393(6682), 266-268.

Ryan, R. M., \& Deci, E. L. (2000). Self-determination theory and the facilitation of intrinsic motivation, social development, and well-being. American Psychologist, 55(1), 764-780.

Ryan, R. M., Rigby, C. S., \& Przybylski, A. K. (2006). The motivational pull of video games: A selfdetermination theory approach. Motivation and Emotion, 30, 347-364.

Schultz, W. (1998). Predictive reward signal of dopamine neurons. Journal of Neurophysiology, 80(1), $1-27$.

Seaborn, K., \& Fels, D. I. (2015). Gamification in theory and action: A survey. International Journal of Human-Computer Studies, 74, 14-31.

\title{
Legal Trends in Organizational Online Social Media Use
}

\author{
Amber N. Schroeder \\ Western Kentucky University \\ Cameron R. Lile \\ SkillSurvey
}

The growth in the popularity of social networking websites (SNSs) has resulted in many organizations using such platforms for organizational activities, including recruitment, employee selection, employee monitoring, and termination. However, the legality of organizations using social networking for these purposes is unclear. Although many researchers have touched on the potential legal implications of organizations using these tools (see e.g., Brown \& Vaughn, 2011), no empirical studies have examined how the court system views their use in organizational settings. Thus, the current study examined federal court cases related to the use of SNSs in various employment practices.

Amber N. Schroeder, Department of Psychological Sciences, Western Kentucky University; Cameron R. Lile, SkillSurvey, Berwyn, Pennsylvania.

Correspondence concerning this article should be addressed to Amber N. Schroeder, Department of Psychological Sciences, Western Kentucky University, 1906 College Heights Boulevard, Number 22030, 3074 Gary Ransdell Hall, Bowling Green, KY 42104-2030. E-mail: amber.schroeder@wku.edu 